\title{
A Case of Desmoplastic Melanoma in a Patient with Parkinson's Disease
}

\author{
Seha Park, Shinyoung Song, Seulki Lee, Heejoo Kim, Jinok Baek, Hyangjoon Park, Jooyoung Roh \\ Department of Dermatology, Gachon University Gil Medical Center, Gachon University College of Medicine, Incheon, Korea
}

\section{Dear Editor:}

Desmoplastic melanoma (DM) is a rare variant of malignant melanoma and constitutes less than $1 \%$ of all cutaneous melanomas ${ }^{1}$. Like all melanomas, especially melanomas of the skin, DM is easily diagnosed in the majority of cases, but some cases can mimic other tumors and cause misdiagnoses. Furthermore, because of the aggressive local behavior and high local recurrence rate of DM, proper diagnosis is essential ${ }^{2,3}$. Recently, there has been much speculation on the relationship between Parkinson's disease (PD) and melanoma, and according to recent retrospective, case-controlled studies, patients with PD are at 4-fold greater risk of having a history of melanoma, and conversely, patients with melanoma are at similar risk of developing PD. In a recent prospective study conducted in North America patients with PD were found to be at 7-fold greater risk of developing melanoma ${ }^{4}$.

A 81-year-old female presented with an erosive, crusted nodule on a violaceous indurated plaque on her nose (Fig. 1A). We received the patient's consent form about publishing all photographic materials. She had been diagnosed with PD 5 years previously and had been treated with levodopa. The clinical differential diagnoses included basal cell carcinoma, squamous cell carcinoma, Merkel

Received March 28, 2019, Revised May 14, 2019, Accepted for publication May 21, 2019

Corresponding author: Jooyoung Roh, Department of Dermatology, Gachon University Gil Medical Center, 21 Namdong-daero 774beon-gil, Namdonggu, Incheon 21565, Korea. Tel: 82-32-460-2763, Fax: 82-32-460-2374, E-mail: jyroh1@gilhospital.com

ORCID: https://orcid.org/0000-0002-9878-6691

This is an Open Access article distributed under the terms of the Creative Commons Attribution Non-Commercial License (http://creativecommons. org/licenses/by-nc/4.0) which permits unrestricted non-commercial use, distribution, and reproduction in any medium, provided the original work is properly cited.

Copyright (c) The Korean Dermatological Association and The Korean Society for Investigative Dermatology cell carcinoma, cutaneous lymphoma, and dermal scar tissue. Histopathologic examination revealed hyperchromatic spindle-shaped cells in dermis mixed with dense collagen bundles (Fig. 1B, C). Neurotropic features and a tendency for malignant, spindle- shaped cells to invade nerves in the dermis were also presented (Fig. 1D). Immunohistochemical staining for S-100 protein, CD 68, cyclin D1, Trichrome, produced positive results for infiltrating spindle-shaped cells but HMB45 was negative (Fig. 2). Based on these findings, a final diagnosis of DM was made (cT4aNOM0, stage IIB). The patient was transferred to another hospital for surgical excision and local skin flap. DM frequently poses diagnostic challenges for dermatologists. Biopsy is necessary for precise diagnosis and proper treatment, because DM is a distinct form of cutaneous melanoma with unique histopathologic and immunohistochemical staining features. Physicians should consider counseling melanoma patients about the risk of PD and undertaking cutaneous melanoma surveillance in PD patients. A family history of melanoma and lighter hair and skin color confer higher risks of developing PD, and having a first-degree relative with either disease conveys an increased risk of developing the other. Possible connections between the two diseases explored, include pigmentation genes in neural-derived cells, pesticides, melanocortin 1 receptor polymorphisms, and abnormal cellular autophagy ${ }^{5}$.

A retrospective review was performed in patient with malignant melanoma to find the association with PD from 2007 to 2017 in our center. Interestingly, 3 out of 43 patients $(7 \%)$ with malignant melanoma had PD. Among melanoma patients over 65 years old, comorbid PD patients were 18 patients $(16.7 \%)$. Future research on this topic will undoubtedly provide further insight into the cause of this relationship as well as necessary screening or patient counseling measures that should be implemented. 

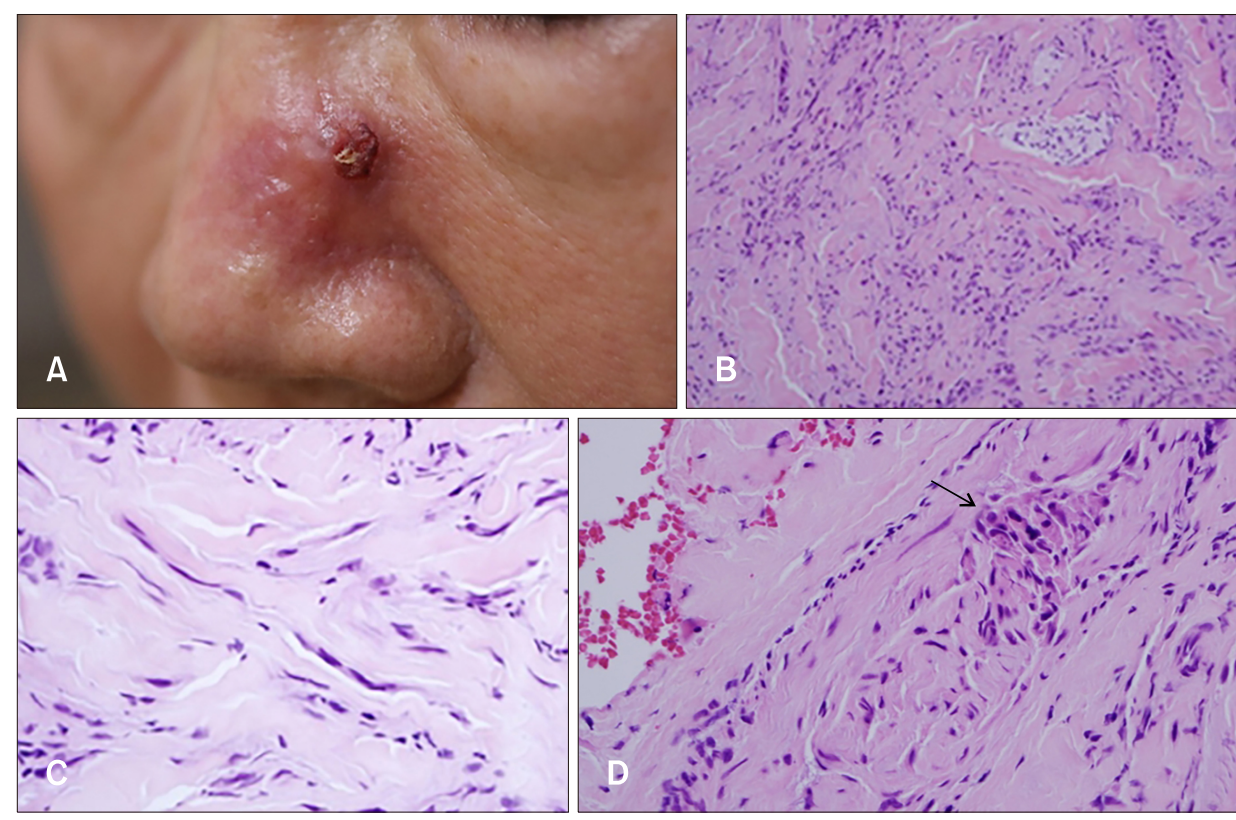

Fig. 1. (A) An erythematous crusted papule with violaceous sclerotic surrounding plaque on the nose. (B) High magnification showing characteristic bundles of malignant, (C) spindle-shaped cells in dermis admixed with collagen bundles. (D) Desmoplastic melanoma with neurotropic features showing malignant spindle-shaped cells tended to invade around nerves $(\mathrm{H} \& \mathrm{E}$, original magnification: $B, \times 200 ; C, \times 400$; D, $\times 400)$.
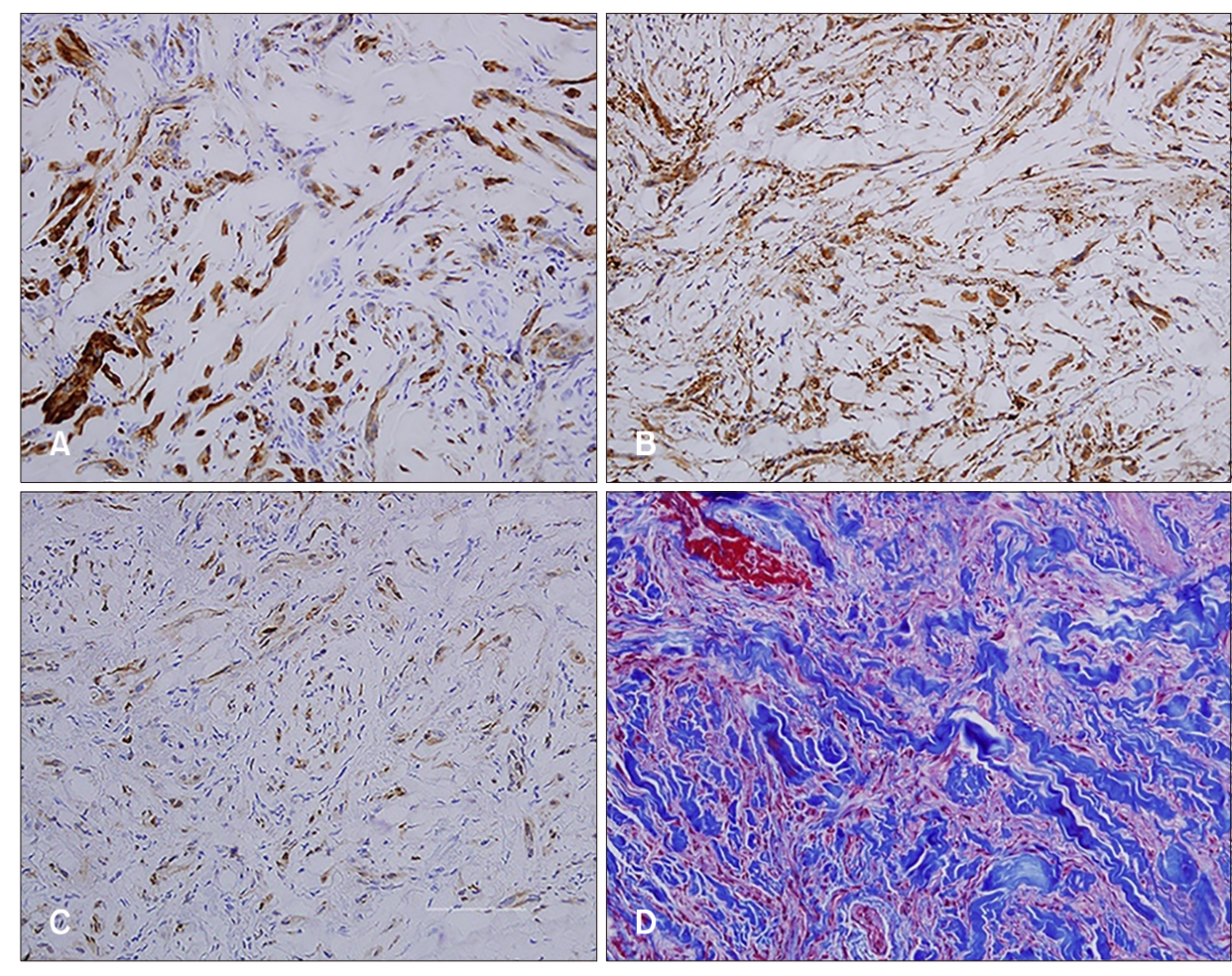

Fig. 2. (A) Histopathologic examination shows positive results for S-100 protein, (B) CD 68, (C) cyclin D, (D) Trichrome, for infiltrating spindle-shaped cells $(A \sim D$ : original magnification $\times 200$ )

\section{CONFLICTS OF INTEREST}

The authors have nothing to disclose.

\section{ORCID}

Seha Park, https://orcid.org/0000-0002-8956-4958

Shinyoung Song, https://orcid.org/0000-0002-5287-3730
Seulki Lee, https://orcid.org/0000-0002-0481-4795 Heejoo Kim, https://orcid.org/0000-0003-1585-8184 Jinok Baek, https://orcid.org/0000-0001-7634-1360 Hyangjoon Park, https://orcid.org/0000-0002-2143-0080 Jooyoung Roh, https://orcid.org/0000-0002-9878-6691 


\section{REFERENCES}

1. Conley J, Lattes R, Orr W. Desmoplastic malignant melanoma (a rare variant of spindle cell melanoma). Cancer 1971;28: 914-936.

2. Posther KE, Selim MA, Mosca PJ, Stanley WE, Johnson JL, Tyler DS, et al. Histopathologic characteristics, recurrence patterns, and survival of 129 patients with Desmoplastic melanoma. Ann Surg Oncol 2006;13:728-739.

3. Lens MB, Newton-Bishop JA, Boon AP. Desmoplastic malig- nant melanoma: a systematic review. Br J Dermatol 2005; 152:673-678.

4. Dalvin LA, Damento GM, Yawn BP, Abbott BA, Hodge DO, Pulido JS. Parkinson disease and melanoma: confirming and reexamining an association. Mayo Clin Proc 2017;92:10701079.

5. Disse M, Reich H, Lee PK, Schram SS. A review of the association between parkinson disease and malignant melanoma. Dermatol Surg 2016;42:141-146.

\title{
A Case of Cutaneous Mycobacterium chelonae Infection Induced by Body Scurbbing
}

\author{
Jee Yon Shin, Dae Hwi Eun, Ji Yeoun Lee, Tae Young Yoon \\ Departments of Dermatology, College of Medicine, Chungbuk National University, Cheongju, Korea
}

\section{Dear Editor:}

A 69-year-old female presented with a 7-month history of multiple variable sized bizarrely shaped ulcers and erosions on the ecchymotic or reddish patches on the neck, chest, and arms (Fig. 1A, B). She had no underlying disease and wasn't taking any medicine which could suppress her own immunity. The lesion originated on the neck, and slowly spread to the chest over a duration of 2 months. After that, it subsequently spread from the chest to the arms over a duration of 3 months. The lesion caused itching and pain. She was treated with antibiotics and topical steroid in local clinics, but her condition had not improved. There was no history of invasive procedure or trauma. The patient's daughter disclosed that she had scrubbed the patient's body daily with an abrasive scrub towel while bathing her. Skin biopsy was performed on her neck and right forearm. Histopathologic findings showed granulomatous inflammation on the dermis and subcutaneous tissue on the both specimens (Fig. 2A, B). Numerous acid-fast bacilli were detected by acid-fast bacilli stain (Fig. 2C) and a polymerase chain reaction revealed Mycobacterium chelonae. The patient was treated with clarithromycin for 6 months, and the lesion has since almost healed.

Atypical mycobacterial infection is caused by mycobacteria, other than Mycobacterium tuberculosis and Мyсоbacterium leprae ${ }^{1}$. Atypical mycobacteria are present in many environmental areas, such as wet soil, water, and in dairy products. Tap water is considered the major reservoir, for nontuberculous mycobacteria pathogens in humans $^{2}$.

M. chelonae is a rapid growing mycobacteria, isolated

Received April 10, 2019, Revised May 21, 2019, Accepted for publication May 21, 2019

Corresponding author: Tae Young Yoon, Department of Dermatology, College of Medicine, Chungbuk National University, 1 Chungdae-ro, Seowon-gu, Cheongju 28644, Korea. Tel: 82-43-269-6369, Fax: 82-43-266-1698, E-mail: tyyoon@chungbuk.ac.kr ORCID: https://orcid.org/0000-0001-6947-1853

This is an Open Access article distributed under the terms of the Creative Commons Attribution Non-Commercial License (http://creativecommons.org/licenses/by-nc/4.0) which permits unrestricted non-commercial use, distribution, and reproduction in any medium, provided the original work is properly cited.

Copyright $($ The Korean Dermatological Association and The Korean Society for Investigative Dermatology 